\title{
Polymorphic forms of the protein L-isoaspartate (D-aspartate) 0 -methyltrans- ferase involved in the repair of age-damaged proteins
}

\begin{abstract}
The protein L-isoaspartate (D-aspartate) $O$ methyltransferase (PCMT1) can initiate the repair of agedamaged aspartyl and asparaginyl residues of intracellular proteins. The human gene PCMT1 encoding this enzyme has at least four polymorphic sites, one of which results in two major isoforms with either an Ile residue or a Val residue at amino acid position 119 . The frequencies of the alleles encoding the $\mathrm{Ile}_{119}$ and $\mathrm{Val}_{119}$ variants are similar in Caucasian populations, but a predominance of the $\mathrm{Ile}_{119}$ allele exists in Asian and African populations. Analyses of the enzymatic activities of the $\mathrm{Ile}_{119}$ and $\mathrm{Val}_{119}$ variants in red blood cell lysates show that the higher specific activity and thermostability of the $\mathrm{Ile}_{119}$ isoform is balanced by the potentially compensating higher substrate affinity of the $\mathrm{Val}_{119}$ isoform. In a preliminary attempt to find an association between genotype frequency at the PCMT1 locus and healthy aging, we compared the distribution of genotypes in a healthy older population of Ashkenazi Jewish individuals with that in a younger ethnically matched control group. We found that $65 \%$ of the healthy older population had the heterozygous genotype, greater than the $50 \%$ expected by Hardy-Weinberg equilibrium, suggesting a possible selection for having both alleles of the repair methyltransferase in successful aging. Three additional polymorphisms in noncoding regions of the methyltransferase gene were found to be biallelic and demonstrated nonrandom association in a specific haplotype with the codon 119 polymorphism. Finally, we also detected a heterozygous mutation in the splicing branch site of intron 2 that did not appear to affect activity. This study will help define the normal physiological range of activity for this repair methyltransferase and give
\end{abstract}

S. Clarke $(\bowtie)$

Department of Chemistry and Biochemistry and the Molecular Biology Institute, University of California, Los Angeles, CA 90095-1569, USA Tel. +1-310-825-8754; Fax +1-310-825-1968

e-mail: clarke@ewald.mbi.ucla.edu

C.G. DeVry

Molecular Biology Institute, University of California, Los Angeles, USA us a better understanding of its role in the processes of aging and disease.

Key words Polymorphism $\cdot$ Isoaspartyl damage $\cdot$ Protein methylation $\cdot$ Protein repair $\cdot$ Aging

\section{Introduction}

Intracellular proteins are subject to a variety of spontaneous chemical degradation reactions (Stadtman 1988; Harding et al. 1989). The resulting altered proteins can have compromised functions and may represent a manifestation of aging at the molecular level. The ability of cells to recognize and repair or degrade such damaged proteins would thus represent an evolutionary adaptation for long-term survival of the organism. Although protein degradation pathways are essential to cellular homeostasis, there is a substantial energy cost to completely degrade and resynthesize a protein. There are also situations where new protein synthesis does not occur or is severely curtailed, such as in mature red blood cells or in long-lived proteins such as the crystallins in the eye lens. These circumstances would favor the repair of damaged proteins as opposed to degradation. The protein L-isoaspartate (D-aspartate) $O$-methyltransferase pathway represents one means of at least partially repairing damaged aspartyl and asparaginyl residues that are susceptible to deamidation, isomerization, and racemization reactions (Fig. 1) (Geiger and Clarke 1987; Patel and Borchardt 1990; Clarke 1999).

The abundance of aspartyl and asparaginyl residues makes most proteins subject to these types of damage, and the nearly ubiquitous expression of this methyltransferase in both prokaryotes and eukaryotes suggests a housekeeping role in preventing the accumulation of damaged proteins (Kagan et al. 1997). In vitro experiments have shown that isoaspartyl damage can decrease the activity of specific proteins such as calmodulin (Potter et al. 1993) and the bacterial HPr phosphocarrier protein (Brennan et al. 1994), and that incubation with the repair methyltransferase and 
Fig. 1. Repair mechanism of the protein Lisoaspartate (D-aspartate) methyltransferase (PCMT1) for the conversion of abnormal Lisoaspartyl residues to $\mathrm{L}$-aspartyl residues. The formation of an isoaspartyl residue occurs from the nucleophilic attack of the peptide-bond nitrogen on the carboxyl group of the aspartyl or asparaginyl side chain via a succinimide ring intermediate. This reaction causes a redirection of the peptide backbone through the side chain and results in a kink in the protein (Lowenson and Clarke 1995). Such damage can result in a structural and subsequent functional change in the protein. The PCMT1 methyltransferase specifically recognizes the damaged form of the residue and initiates the repair cycle by transferring a methyl group from $S$-adenosyl methionine to the $\alpha$ carboxyl group of the L-isoaspartyl residue. The methyl ester forms spontaneously demethylate to give the cyclic L-succinimide residue that can regenerate the normal L-aspartyl residue by hydrolysis. Although the succinimide ring can also open to the Lisoaspartyl form, the constitutive presence of the methyltransferase leads to the net reconversion to the $\mathrm{L}$-aspartyl residue in additional cycles of the reaction (Johnson et al. 1987b; McFadden and Clarke 1987). AdoMet, $S$-adenosyl methionine; AdoHcy, $S$ adenosyl homocysteine

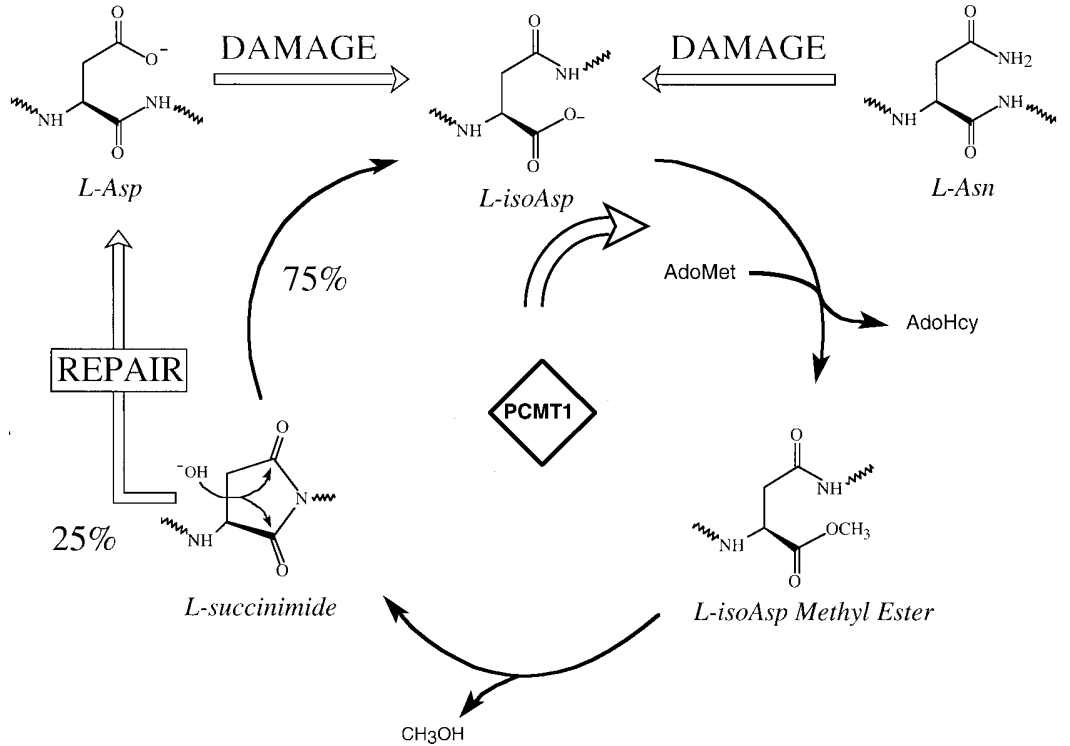

the methyl-donating substrate $S$-adenosylmethionine can restore activity (Johnson et al. 1987a; Brennan et al. 1994). This type of damage is also found in the $\beta$-amyloid plaques of Alzheimer's Disease (Roher et al. 1993) and in cataractous eye lens tissue (McFadden and Clarke 1986), two common biomarkers of aging. The importance of repairing these damaged residues is most apparent in a mouse knockout model of the repair methyltransferase which shows substantially elevated levels of isoaspartyl damage in tissue proteins, coupled with the death of the mice within 40-50 days (Kim et al. 1997).

We have also been interested in the role of the human protein L-isoaspartate (D-aspartate) methyltransferase in the pathophysiology of the aging process. This enzyme is encoded by a single gene, PCMT1, that has been mapped to the q24-25 region of chromosome 6 (MacLaren et al.1992b; DeVry and Clarke 1999) and is comprised of eight exons spanning approximately $60 \mathrm{~kb}$ of genomic DNA (DeVry et al. 1996). Interestingly, the initial characterization of the human cDNA clones and peptide sequencing revealed allelic variations that suggested it was polymorphic (Ingrosso et al. 1989; MacLaren et al. 1992a; Tsai and Clarke 1994). We have subsequently begun to characterize the extent and complexity of these variations and have examined their effects on enzymatic activity. Recent studies have shown that the specific activity of the protein L-isoaspartate (Daspartate) methyltransferase is influenced by the identity of the amino acid residue at position 119 (David et al. 1997). This polymorphic site has been characterized by a transition base substitution in the third position of codon 119 that results in either an Ile or Val residue (Tsai and Clarke 1994). Using red blood cell cytosolic fractions from a population of individuals with known genotype, higher specific activity and thermostability was seen for the $\mathrm{Ile}_{119}$ homozy- gotes compared with $\mathrm{Ile}_{119} / \mathrm{Val}_{119}$ and with the $\mathrm{Val}_{119}$ homozygotes (David et al. 1997).

In this paper, we expand the study of the position 119 polymorphism and establish its allele frequencies in different ethnic populations. Moreover, we show that the thermostability of the $\mathrm{Ile}_{119}$ variant is balanced by an increased affinity of substrate recognition by the $\mathrm{Val}_{119}$ variant. We also find an intriguing association when allele frequencies are compared between successfully aged individuals and younger ethnically matched controls. Finally, we perform a comprehensive screen of the PCMT1 coding and flanking intron sequence to identify additional polymorphisms in the repair methyltransferase gene.

\section{Materials and methods}

\section{Subjects}

The population study of the polymorphism at amino acid position 119 in the PCMT1 gene product included 395 unrelated individuals from the Los Angeles area, and 25 Norwegian and 20 Korean individuals collected by Dr. Richard Weinshilboum at the Mayo Clinic in Rochester, Minnesota. To ask if a correlation could be made between PCMT1 genotype and healthy aging in human populations, 40 Ashkenazi Jewish individuals (31 women and 9 men; 75-104 years old; average age, 87.2 years) were studied as representatives of a successfully aged population that were communicative, ambulatory, self-sufficient, and living independently in a retirement community. Clinical histories were not available to establish any additional exclusion criteria. In order to compare this group with an ethnically matched younger popula- 
tion, 40 Ashkenazi Jewish individuals (14 women and 26 men, 21-74 years old; average age, 36.2 years) were studied from the same metropolitan community. Human studies were approved by the Human Subject Protection Committee at the University of California, Los Angeles (UCLA) and at the Jewish Home for the Aging in Reseda, California.

\section{Genotyping}

For the 395 individuals that were studied, genomic DNA was isolated from buccal samples that were obtained with informed consent from healthy volunteer subjects. Cells were collected on a sterile histology brush (Puritan Medical Products, Guilford, Maine, USA) by gently brushing the inner cheek for approximately 5-10s. Genomic DNA was prepared from the cheek cells as described by Richards et al. (1993) with the exception that the brush was immediately immersed in $1 \mathrm{ml}$ of phosphate-buffered saline solution $(\mathrm{pH}$ 7.4) contained in a polypropylene microcentrifuge tube and vigorously twirled to release the cells. The brush was then removed and the cells were spun down at $14,000 \mathrm{~g}$ for $1 \mathrm{~min}$. The pellet was then resuspended in $600 \mu \mathrm{l}$ of $50 \mathrm{mM} \mathrm{NaOH}$. After a 5-min incubation at $95^{\circ} \mathrm{C}, 60 \mu \mathrm{l} 1 \mathrm{M}$ Tris $(\mathrm{pH} 7.4)$ was added to neutralize the solution and the buccal cell lysate containing genomic DNA was stored at $-20^{\circ} \mathrm{C}$. For the Norwegian and Korean samples, purified DNA was provided by Dr. Richard Weinshilboum.

Single-stranded conformational polymorphism (SSCP) screens were carried out by PCR amplification of each PCMT1 exon (DeVry et al. 1996) using the primers listed in Table 1 , followed by mutation detection enhanced polyacrylamide gel electrophoresis (Bailey 1995). Oligonucleotide primer synthesis and purification was performed by GIBCO BRL (Life Technologies, Grand Island, NY, USA). PCR reaction mixtures $(25 \mu \mathrm{l})$ contained 20 pmol of each primer, $20 \mu \mathrm{M}$ of a dNTP mix containing all four deoxyribonucleotide triphosphates (Pharmacia Biotech, Piscataway, NJ, USA), $1 \times$ reaction buffer (Promega, Madison, WI, USA), $3 \mathrm{mM} \mathrm{MgCl}, 1 \mathrm{U}$ Taq DNA polymerase (Promega), $5 \mu$ l buccal lysate containing genomic DNA, and $0.5 \mu \mathrm{l}$ of $3000 \mathrm{Ci} / \mathrm{mmol}\left[\alpha{ }^{32} \mathrm{P}\right] \mathrm{dCTP}$ (ICN Radiochemicals, Irvine, CA, USA). The $\mathrm{MgCl}_{2}$ was added as a HotWax $\mathrm{Mg}^{2+}$ bead (Invitrogen, San Diego, CA USA) to initiate a hot start PCR. The PCR cycling conditions for each amplification were $95^{\circ} \mathrm{C}$ for $2 \mathrm{~min}$ as an initial denaturation step and then 30 cycles of $95^{\circ} \mathrm{C}$ for $30 \mathrm{~s}, 55^{\circ} \mathrm{C}$ for $30 \mathrm{~s}$, and $72^{\circ} \mathrm{C}$ for $30 \mathrm{~s}$, followed by a final extension step at $72^{\circ} \mathrm{C}$ for $5 \mathrm{~min}$. A $2-\mu l$ aliquot of the reaction mixture was added to $9 \mu l$ of loading buffer containing $95 \%$ formamide, $10 \mathrm{mM} \mathrm{NaOH}$,

Table 1. Sequences of primers used for PCR amplification and DNA sequencing

\begin{tabular}{|c|c|c|}
\hline Primer & Exon & Sequence \\
\hline $\begin{array}{l}\text { CDI1F2 } \\
\text { E1F' (BT1F) } \\
\text { CDI1F } \\
\text { CD1R } \\
\text { CDI1R4 }\end{array}$ & 1 & $\begin{array}{l}\text { 5'-CTAAGCCGCGGCGTCACAGAGC-3' } \\
\text { 5'-TGTGCTTAGCGATGGCCTGGAAATC-3' } \\
\text { 5'-GGTGACGGTGTGGGAGGTGG-3' } \\
\text { 5'-GGTGGCACTTACTGCGGAGATTGTGG-3' } \\
\text { 5'-GCAACTCTGCGCCGAACCCTCC-3' }\end{array}$ \\
\hline $\begin{array}{l}\text { E2R (BT2R) } \\
\text { 2INF5' } \\
\text { VB22LEUF } \\
\text { VBE2F } \\
\text { 2INF3' }\end{array}$ & 2 & $\begin{array}{l}\text { 5'-CTGTAGCCAGCATCACTTCAAATAC-3' } \\
\text { 5'-CAGTCTCTATAGCACAGCTGGTGTA-3' } \\
\text { 5'-CTTGTTTCAGAAAATGGAATCCTCAAG-3' } \\
\text { 5'-CTTGTTTCAGAAAATGGAATC-3' } \\
\text { 5'-GTGTCCCAGGCTTTTTCT-3' }\end{array}$ \\
\hline $\begin{array}{l}\text { I3F } \\
\text { CDI3R }\end{array}$ & 3 & $\begin{array}{l}\text { 5'-TATTGTGAAAAATAACGTATGGA-3' } \\
\text { 5'-TGTAACCAAGTGAACAAAC-3' }^{\prime}\end{array}$ \\
\hline $\begin{array}{l}\text { CDI4F2 } \\
\text { CDI4F } \\
\text { CDE4F2 } \\
\text { CDI4R } \\
\text { E4R (BT4R) }\end{array}$ & 4 & $\begin{array}{l}\text { 5'-TGGCAGATAGCAAGATAACTTGG-3' } \\
\text { 5'-CCATGATGTGTGTACTTTAGTC-3' } \\
\text { 5'-CATGCATATGCGCTAGAACTTC-3' } \\
\text { 5'-CATATAATATTCTTCTGTTGGGGCC-3' } \\
\text { 5'-GCTTTAGCTCCTTCATGCAACTG-3' }\end{array}$ \\
\hline $\begin{array}{l}\text { E5F (DM5) } \\
\text { EX5F } \\
\text { E5R (BT5R) } \\
\text { E5R' (DM6) } \\
\text { I5R }\end{array}$ & 5 & $\begin{array}{l}\text { 5'-GTTGGATGTACTGGAAAAGTCATAGG-3' } \\
\text { 5'-GATAAACTGAGTGTTTAGCAATC-3' } \\
\text { 5'-CTGAGTCATCTACTAGCTCTTTAATG-3' } \\
\text { 5'-CAAGCTGTACTCTCCCTGAAGACAG-3' } \\
\text { 5'-CTCTGAGTATTATTTAGCTTGCATTGG-3' }\end{array}$ \\
\hline $\begin{array}{l}\text { CDI6F } \\
\text { CDI6R }\end{array}$ & 6 & $\begin{array}{l}\text { 5'-CCTCCTGTACTAGAATTCTTCAC-3' } \\
\text { 5'-CACACAAACAGAAAAAATCCCG-3' }\end{array}$ \\
\hline $\begin{array}{l}\text { CDI7F2 } \\
\text { E7aF (DM4) } \\
\text { E7aF' } \\
\text { CDE7cR } \\
\text { E7aR' (DM3) }\end{array}$ & 7 & $\begin{array}{l}\text { 5'-CTGTAACTTGGTGATGTATGTGC-3' } \\
\text { 5'-GTTAAAGCCCGGAGGAAGATTGATATTG-3' } \\
\text { 5'-AAATGAAGCCTCTGATGGG-3' } \\
\text { 5'-GCTCTTGTAGTCTAATGTCTTAAAATCACACCC-3 } \\
\text { 5'-GGACCACTGCTTTTCTTTATCTG-3' }\end{array}$ \\
\hline $\begin{array}{l}\text { VNTRF } \\
\text { VNTRR }\end{array}$ & 8 & $\begin{array}{l}\text { 5'-CTTTAAGGGAGCATGAATAAATGGG-3' } \\
\text { 5'-GTTGCCCTTCATATTATGTAAAGG-3' }\end{array}$ \\
\hline
\end{tabular}


$0.05 \%$ bromophenol blue, and $0.05 \%$ xylene cyanol. The samples were then incubated at $95^{\circ} \mathrm{C}$ for $5 \mathrm{~min}$ and immediately placed on ice. Conformation polymorphisms of singlestranded DNA fragments were analyzed using nondenaturing polyacrylamide gels $(40 \times 30 \times 0.04 \mathrm{~cm})$ made in one of the following ways. Gels containing $0.5 \times$ mutation detection enhancement (MDE) (FMC BioProducts, Rockland, Maine, USA) with $10 \%$ glycerol were run in $0.6 \times$ Tris-borate electrophoresis buffer (TBE) buffer at $5 \mathrm{~W}$ overnight at room temperature using a BioRad Power Pac 3000 (Madison, WI, USA). Gels containing $0.5 \times \mathrm{MDE}$ without glycerol were run in $0.6 \times \mathrm{TBE}$ buffer at $8^{\circ} \mathrm{C}$ for $6 \mathrm{~h}$ at $15 \mathrm{~W}$. The gel was dried under vacuum for $1 \mathrm{~h}$ at $70^{\circ} \mathrm{C}$ and the DNA fragments were visualized by autoradiography (Kodak X-OMAT AR film, Rochester, NY, USA) at room temperature for 1-2 days. When signal intensity was weak, a 1- to 2-day exposure was done at $-80^{\circ} \mathrm{C}$ with an intensifying screen. To scan the entire coding region for additional polymorphisms of the PCMT1 gene, primers were designed for PCR amplification to span each exon but also to include the splice site consensus sequences (Table 1). To maintain PCR products of less than $200 \mathrm{bp}$ for the subsequent SSCP analysis, multiple overlapping primer sets were often used to span a single exon.

In the analysis of the dinucleotide repeat polymorphism in the $3^{\prime}$-untranslated region, the procedure of Litt et al. (1993) was followed to avoid the problem of "shadow banding", which can make it difficult to score alleles reliably. The VNTRF primer was end-labeled with $\left[\gamma^{32} \mathrm{P}\right]$ ATP ( $>6000 \mathrm{Ci} / \mathrm{mmol} ; \mathrm{ICN}$ ) and $\mathrm{T}_{4}$ polynucleotide kinase (New England Biolabs, Beverly, MA, USA) for $1 \mathrm{~h}$ at $37^{\circ} \mathrm{C}$. The 50- $\mu$ l PCR mixture contained $1 \times$ buffer (Promega), a 3.5$\mathrm{mM} \mathrm{MgCl}_{2}$ HotWax bead (Invitrogen), $200 \mu \mathrm{M}$ of each dNTP (GIBCO BRL), 320ng each of the unlabeled primers VNTRF and VNTRR (Table 1), 40ng of the ${ }^{32}$ P-labeled primer, $5 \mu$ l of buccal genomic DNA lysate, and $2 \mathrm{U}$ of Taq DNA polymerase (Promega). The PCR cycling parameters were carried out as described above for the PCR-SSCP. A $5-\mu l$ aliquot of the PCR reaction was mixed with $10 \mu \mathrm{l}$ of a loading buffer containing $95 \%$ formamide, $10 \mathrm{mM}$ ethylene diamine tetraacetic acid (EDTA), $0.05 \%$ bromophenol blue, and $0.05 \%$ xylene cyanol and incubated at $95^{\circ} \mathrm{C}$ for $5 \mathrm{~min}$ prior to loading. From this diluted mixture, $5 \mu \mathrm{l}$ of each sample was run on $7 \%$ acrylamide, $30 \%$ formamide, $6 \mathrm{M}$ Urea, $0.6 \times \mathrm{TBE}$ gel $(40 \times 30 \times 0.04 \mathrm{~cm})$ for $2 \mathrm{~h}$ at $50 \mathrm{~W}$. The gel was subsequently dried down under vacuum for $1 \mathrm{~h}$ at $70^{\circ} \mathrm{C}$ and exposed to autoradiographic film (Kodak XOMAT AR).

For the purposes of restriction digests and DNA sequencing, DNA was amplified in a 50- $\mu$ l PCR reaction using 40 pmol of each exon-specific primer, $1 \times$ reaction buffer (Promega), 200 $\mu \mathrm{M}$ of a dNTP mix containing all four deoxyribonucleotide triphosphates, a 3.5-mM Hotwax $\mathrm{MgCl}_{2}$ bead, 2U Taq DNA polymerase, and $10 \mu \mathrm{l}$ buccal lysate containing genomic DNA. The PCR cycling conditions consisted of the parameters descibed above. DNA was isolated from the reaction mixture using the Wizard PCR Prep DNA Purification System (Promega). Restriction digest analyses for the codon 119 polymorphism were carried out with $10 \mathrm{U}$ of the enzyme $\mathrm{DdeI}$ (GIBCO BRL) at $37^{\circ} \mathrm{C}$ for
$2 \mathrm{~h}$ and visualized on a $1.2 \%$ agarose gel stained with ethidium bromide. PCR reactions to be sequenced were submitted to UCLA's DNA Sequencing Facility for analysis with the ABI Fluorescent Sequencing System (PerkinElmer, Norwalk, CT, USA).

\section{Methyltransferase activity assays}

Methyltransferase activity was examined in red blood cell cytosolic fractions prepared from individuals of known genotype for the polymorphism at amino acid position 119. Blood (approximately 200 $\mu$ l) was collected after informed consent by pricking the finger with a sterile microlancet, and was transferred to a 1-ml solution of phosphate-buffered saline containing $2 \mathrm{mg} / \mathrm{ml}$ disodium EDTA at $\mathrm{pH} 7.4$. The red blood cells were isolated by centrifugation at $14,000 \mathrm{~g}$ at $4{ }^{\circ} \mathrm{C}$ for $2 \mathrm{~min}$. After approximation of the volume of packed red blood cells and discarding of the supernatant, the cells were resuspended in 5 volumes of lysis buffer containing $5 \mathrm{mM}$ sodium phosphate (monobasic), $1 \mathrm{mM}$ ethyleneglycoltetraacetic acid (EGTA) at pH 7.4, and $25 \mu \mathrm{M}$ phenylmethylsulfonyl fluoride (PMSF). The resuspended cells were frozen in dry ice for $30 \mathrm{~min}$ to aid lysis and then centrifuged at $14,000 \mathrm{~g}$ at $4^{\circ} \mathrm{C}$ for $5 \mathrm{~min}$ to pellet the membrane fraction. The cytosol was transferred to a new tube and the protein concentration was determined by a modification of the Lowry assay, using bovine serum albumin as a standard (Bailey 1967).

The activity of the protein L-isoaspartyl (D-aspartyl) methyltransferase was determined using the vapor-phase diffusion method (Macfarlane 1984). The L-isoaspartyl containing protein ovalbumin $(5 \mu \mathrm{l}$ of an $80 \mathrm{mg} / \mathrm{ml}$ stock; Grade $\mathrm{V}$; Sigma, St. Louis, MO, USA) was added to $5 \mu 1$ red blood cell cytosol and $10 \mu \mathrm{l}$ of $0.2 \mathrm{M}$ Bis-Tris buffer $\mathrm{pH} 6$, in a microcentrifuge tube. Following the addition of $10 \mu \mathrm{l}$ of $30 \mu \mathrm{M}$ S-adenosyl- $\left[\right.$ methyl $\left.-{ }^{14} \mathrm{C}\right]$-methionine (in $0.2 \mathrm{M}$ bisTris, $\mathrm{pH}$ 6; $55 \mathrm{mCi} / \mathrm{mmol}$; Amersham, Arlington Heights, IL, USA) the reaction mixture was incubated at $37^{\circ} \mathrm{C}$ for $20 \mathrm{~min}$ and the reaction was terminated by placing the tube on dry ice. The reaction mixture was then thawed and $60 \mu \mathrm{l}$ of $0.2 \mathrm{M} \mathrm{NaOH}$ was added to convert the radiolabeled methyl esters to $\left[{ }^{14} \mathrm{C}\right]$ methanol. Immediately after the addition of base, the reaction was spotted onto a $1.9 \mathrm{~cm} \times 10.2 \mathrm{~cm}$ piece of thick filter paper (BioRad gel dryer paper no. 1650962) that had been folded in an accordion pattern. This filter paper was then placed in the neck of a scintillation vial suspended above $5 \mathrm{ml}$ of Safety-Solve Counting Fluid (Research Products International, Mount Prospect, IL, USA) and capped tightly. After a 2-h incubation time at room temperature, the filter paper was discarded and the scintillation fluid was counted three times for 5-min intervals in a Beckman LS 6500 scintillation counter. Specific activities were measured as pmol of methyl groups transferred per min per mg of red blood cell cytosolic protein.

The thermal stability of methyltransferase variants was determined by preincubating the red blood cell cytosols at a protein concentration of $23-33 \mathrm{mg} / \mathrm{ml}$ with $0.2 \mathrm{M}$ Bis-Tris buffer ( $\mathrm{pH} 6.5$ ) at $0^{\circ} \mathrm{C}, 37^{\circ} \mathrm{C}, 48^{\circ} \mathrm{C}, 50^{\circ} \mathrm{C}$, and $52^{\circ} \mathrm{C}$ for a period 
of $15 \mathrm{~min}$ prior to measuring enzyme activity as described above. Similarly, oxidative stability was determined by preincubating the red blood cell cytosols at a protein concentration of $46-78 \mathrm{mg} / \mathrm{ml}$ in various concentrations of $\mathrm{H}_{2} \mathrm{O}_{2}$ and $1 \mathrm{mg} / \mathrm{ml}$ sodium azide (to inhibit catalase activity) for $15 \mathrm{~min}$.

\section{Statistical analysis}

$\chi^{2}$ analysis was utilized in comparisons of allele and genotype frequencies between ethnic groups in the population study, as well as in comparisons between young and old populations in the successful aging study. Analysis of variance was performed to compare the activities of the repair methyltransferase enzyme between individuals of different genotype, and a Students's $t$-test was used to compare both $\mathrm{V}_{\text {max }}$ and $\mathrm{K}_{\mathrm{m}}$ means between homozygous genotypes in kinetic studies. Values represent the means \pm SEM. These calculations were carried out with the statistical programs Excel (Microsoft, Redmond, WA, USA) and Prism (GraphPad, San Diego, CA, USA).

\section{Results}

Population study of the amino acid 119 polymorphism in the human protein L-isoaspartate (D-aspartate) methyltransferase

The frequency of variation at the amino acid 119 polymorphic site within this methyltransferase was determined in a population study of 440 individuals. Using genomic DNA, individuals were genotyped using PCR-SSCP analysis for the AAT codon leading to isoleucine ${ }_{119}$ or the GAT codon leading to valine $_{119}$ (Fig. 2). The sequence-specific single strand conformations of the $\mathrm{Ile}_{119}$ homozygous genotype are represented by a doublet banding pattern and the $\mathrm{Val}_{119}$ homozygous genotype is represented by a single band. The presence of both banding patterns represents a heterozygous genotype. These banding patterns were initially correlated with specific genotypes by sequence analysis (Fig. 2) and restriction digestion (data not shown). The presence of a $G$ nucleotide in the third position of codon 119 creates a recognition site for the DdeI restriction enzyme. The population distributions found for each genotype are given in Table 2. Although no gender-specific differences were observed, significant differences in the distribution of genotypes were observed between certain ethnic groups for which we had an adequate number of samples for comparison. Specifically, the Caucasian allele and genotype frequencies were significantly different from those in both the Asian and African ethnic groups. The allele frequency in the Caucasian population was 0.45 for $\mathrm{Ile}_{119}$ and 0.55 for $\mathrm{Val}_{119}$, while in the Asian population the allele frequency was 0.88 for $\mathrm{Ile}_{119}$ and 0.12 for $\mathrm{Val}_{119}(P<0.0001)$. Similar to the Asian population, the African population had allele frequencies of 0.81 and 0.19 for $\mathrm{Ile}_{119}$ and $\mathrm{Val}_{119}$, respectively, that were significantly different from Caucasians $(P$ $<0.0001)$. The differences between Asian and African were not significant $(P=0.14)$. Based on the observed allele frequencies, the calculated best fit population distribution was very similar to the observed distribution in all ethnic groups, confirming a Hardy-Weinberg equilibrium. Three homogeneous populations within the Caucasoid group (Indian, Ashkenazi Jewish, and Norwegian) showed similar genotypic distributions and were not significantly different from the total Caucasian group $(P=0.80 ; P=0.77$; and $P$ $=0.32$, respectively). Within the Asian group, however, there appear to be some differences between the individual populations. The Chinese and Korean populations, the only two with adequate numbers for comparison in this group, were significantly different from each other $(P=0.016)$. The number of individuals in other ethnic groups was insufficient to make any other comparisons.

Table 2. Population study of the polymorphism at amino acid position 119

\begin{tabular}{|c|c|c|c|c|c|}
\hline \multirow[b]{2}{*}{ The study population $(n=440)$} & \multicolumn{3}{|c|}{ No. of individuals/genotype (\% of total) } & \multicolumn{2}{|c|}{ Allele frequency ${ }^{\mathrm{a}}$} \\
\hline & Ile/Ile & Ile/Val & $\mathrm{Val} / \mathrm{Val}$ & Ile & Val \\
\hline Caucasian $(n=284)$ & $55(19.4)$ & $144(50.7)$ & $85(29.9)$ & 0.447 & 0.553 \\
\hline Ashkenazi Jewish $(n=80)$ & $15(18.8)$ & $44(55.0)$ & $21(26.2)$ & 0.462 & 0.538 \\
\hline Indian $(n=31)$ & $6(19.3)$ & $14(45.2)$ & $11(35.5)$ & 0.419 & 0.581 \\
\hline Norwegian ${ }^{\mathrm{b}}(n=25)$ & $8(32.0)$ & $11(44.0)$ & $6(24.0)$ & 0.540 & 0.460 \\
\hline Other Caucasian $(n=148)$ & $26(17.5)$ & $75(50.7)$ & 47 (31.8) & 0.429 & 0.571 \\
\hline Asian $(n=96)$ & $72(75.0)$ & $24(25.0)$ & 0 & 0.875 & 0.125 \\
\hline Chinese $(n=39)$ & $35(89.7)$ & $4(10.3)$ & 0 & 0.949 & 0.051 \\
\hline Korean $(n=33)$ & $22(66.7)$ & $11(33.3)$ & 0 & 0.833 & 0.167 \\
\hline Japanese $(n=6)$ & $2(33.3)$ & $4(66.7)$ & 0 & & \\
\hline Vietnamese $(n=5)$ & $4(80.0)$ & $1(20.0)$ & 0 & & \\
\hline Other Asian $(n=13)$ & $9(69.2)$ & $4(30.8)$ & 0 & & \\
\hline African $(n=40)$ & $25(62.5)$ & $15(37.5)$ & 0 & 0.812 & 0.188 \\
\hline Hispanic $(n=14)$ & $3(21.4)$ & $7(50.0)$ & $4(28.6)$ & & \\
\hline Mixed $(n=6)$ & $2(33.3)$ & $3(50.0)$ & $1(16.7)$ & & \\
\hline
\end{tabular}

${ }^{\text {a }}$ Allele frequency only reported in population $n \geq 25$

${ }^{b}$ Norwegian samples collected by Dr. Richard Weinshilboum at the Mayo Clinic in Rochester, Minnesota 
Fig. 2. Detection of amino acid polymorphism at codon position 119 of PCMT1 by polymerase chain reaction-single-stranded confornational polymorphism (PCRSSCP) and DNA sequencing. A 117-bp region of exon 5 was amplified by PCR with the primers DM5 and DM6 (Table 1). The labeled PCR products were separated by polyacrylamide gel electrophoresis (PAGE) following the SSCP protocol as described in "Materials and Methods". Individuals homozygous for the $\mathrm{Val}_{119}$ allele presented a single band (lanes 2 and 4), while individuals homozygous for $\mathrm{Ile}_{119}$ presented a and 5). Heterozygous individuals demonstrated a combination of both banding patterns (lane 1) doublet banding pattern (lanes 3

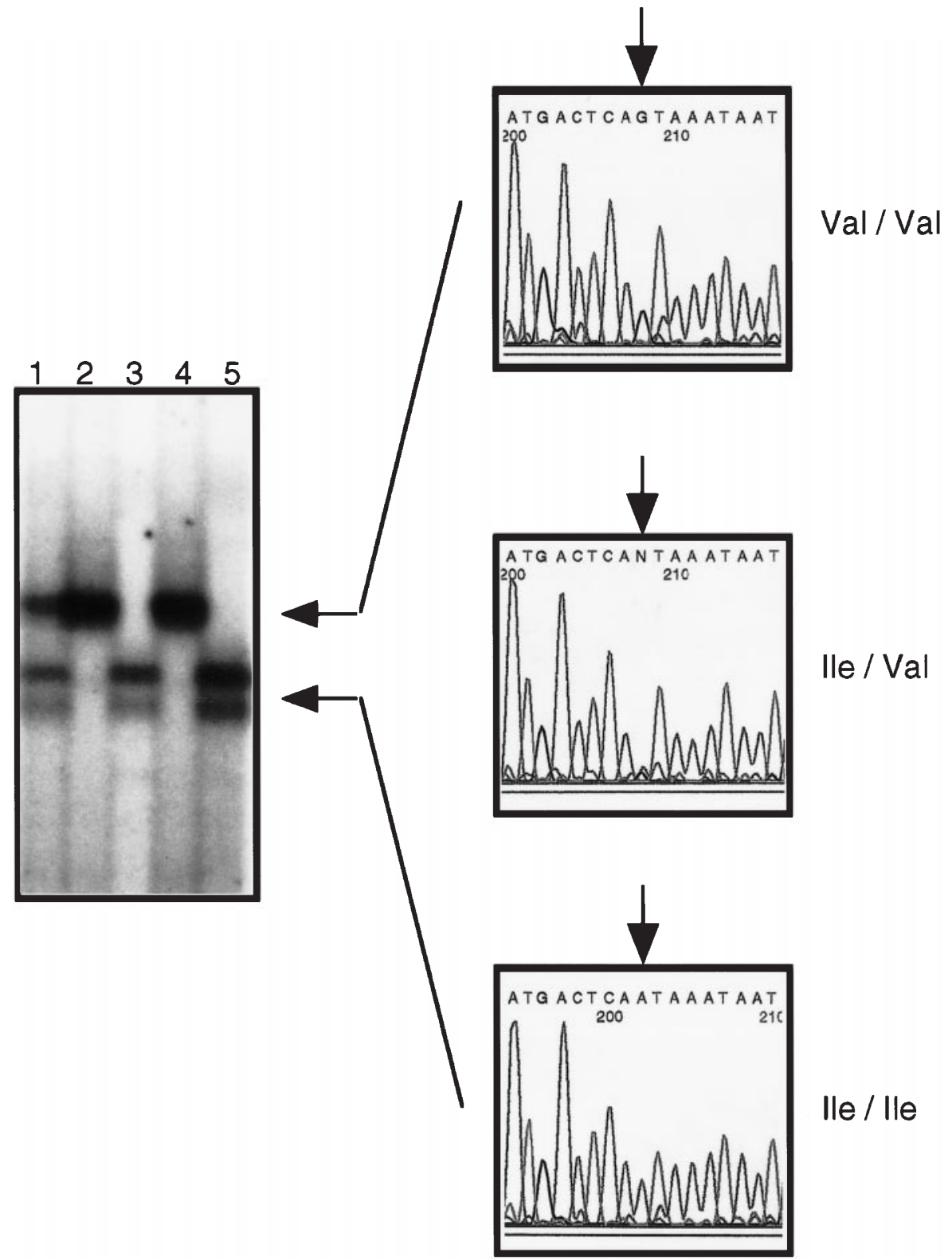

Enzymatic differences of the human PCMT1 polymorphic variants

To determine the functional consequence of the $\mathrm{Ile}_{119} / \mathrm{Val}_{119}$ polymorphism, a series of enzymatic analyses were conducted with cytosolic extracts from red blood cells of individuals of known genotype. Specific activity differences were determined by measuring the initial velocity of a reaction with saturating levels of the methyl-accepting substrate ovalbumin and the methyl-donating substrate Sadenosylmethionine, using a vapor phase diffusion assay. In four independent experiments with representatives of each genotype $(n=4)$, a small but significant difference was observed between the means of each homozygous genotype group $(P=0.013)$, as determined by a one-way analysis of variance (ANOVA) (Fig. 3A). The average activity for the four $\mathrm{Ile}_{119}$ representatives of $4.4( \pm 0.19 \mathrm{SEM}) \mathrm{pmol} / \mathrm{min}$ per mg was approximately $20 \%$ higher than that of the $\mathrm{Val}_{11}$ individuals, which averaged $3.4( \pm 0.19 \mathrm{SEM}) \mathrm{pmol} / \mathrm{min}$ per $\mathrm{mg}$. Intermediate values of $4.0( \pm 0.15 \mathrm{SEM})$ were observed for the heterozygotes. A Tukey's multiple comparison test of the data found a significant difference of means specifically between the $\mathrm{Ile}_{119} / \mathrm{Ile}_{119}$ and $\mathrm{Val}_{19} / \mathrm{Val}_{119}$ homozygous genotypes $(P<0.01)$, with a mean differ-ence of $0.96 \mathrm{pmol} /$ min per $\mathrm{mg}$ (95\% confidence interval [CI]: 0.26-1.7).

Such differences in the specific activity of the enzyme in red blood cells can result from differences in the stability of the enzyme, as well as from its intrinsic ability to methylate ovalbumin (cf. refs. Frosst et al. 1995; Lotta et al. 1995). We thus measured the effect this amino acid substitution has on the temperature stability of the enzyme by preincubating representative red blood cell cytosolic fractions from four 
individuals of each genotype for $15 \mathrm{~min}$ at a range of temperatures (Fig. 3B). This preincubation was immediately followed by initial velocity assays, using the substrate ovalbumin as described above. A two-way ANOVA established that genotype had a significant effect on thermostability $(P<0.0001)$. The results showed that the $\mathrm{Ile}_{119}$ enzyme was significantly more thermotolerant than the $\mathrm{Val}_{119}$ enzyme at all preincubation temperatures $\left(48^{\circ} \mathrm{C}, 50^{\circ} \mathrm{C}\right.$, and $\left.52^{\circ} \mathrm{C}\right)(P$ $=0.0005)$. After preincubation at $50^{\circ} \mathrm{C}$, the $\mathrm{Ile}_{119}$ homozygous cytosol maintained an approximately four fold higher activity than the $\mathrm{Val}_{119}$ homozygous cytosol. The $\mathrm{Ile}_{119} / \mathrm{Ile}_{119}$ cytosol retains $41 \%$ of its initial activity at $50^{\circ} \mathrm{C}$ while the $\mathrm{Val}_{119} / \mathrm{Val}_{11}$ cytosol retains only $11 \%$ of its initial activity. The greater stability of the $\mathrm{Ile}_{119}$ enzyme may account for the higher activity of this enzyme as compared with the $\mathrm{Val}_{119}$ enzyme in the red blood cell, which has an average age of about 60 days in the circulation (Bartosz 1990). Similar stability assays were performed with oxidative stress in which red blood cell cytosols from two representatives of each genotype were preincubated with various concentrations of $\mathrm{H}_{2} \mathrm{O}_{2}$ in three independent experiments (Fig. 3C). The genotype did effect the result (two-way ANOVA; $P=0.0024$ ), with the activity of the $V a_{119}$ enzyme being consistently lower than that of the $\mathrm{Ile}_{119}$ enzyme after a 15-min preincubation at final concentrations of $7.7,15.4,30.8,76.9$, and $153.8 \mathrm{mM}$. However, the genotype did not have the same level of effect at all values of $\mathrm{H}_{2} \mathrm{O}_{2}$ concentration. The $\mathrm{H}_{2} \mathrm{O}_{2}$ concentration with greatest effect was $30.8 \mathrm{mM}$, at which an approximately $10 \%$ difference in activity was observed.

To investigate the possibility of differences in substrate recognition specificities between the codon 119 variants, activity assays were performed with a number of different isoaspartyl-containing peptide substrates for which the repair methyltransferase is known to have varying affinity (Lowenson and Clarke 1991). The reactions were carried out at saturating concentrations for each peptide. After normalizing for the differences observed with ovalbumin that might be attributable to enzyme levels associated with the differences in stability, there was no appreciable differ-

Fig. 3A-C. Differences in L-isoaspartyl methyltransferase activity and stability between PCMT1 polymorphic variants of amino acid position 119. A The specific activity was measured as $\mathrm{pmol} / \mathrm{min}$ per $\mathrm{mg}$ protein with red blood cell cytosolic extracts prepared from individuals $(n=4)$ of each genotype, using ovalbumin as substrate. Error bars indicate the standard error of the mean in four independent experiments. B Red blood cell cytosols from four unrelated individuals of each genotype were preincubated at either $37^{\circ} \mathrm{C}, 48^{\circ} \mathrm{C}, 50^{\circ} \mathrm{C}$, or $52^{\circ} \mathrm{C}$ for $15 \mathrm{~min}$ prior to the methyltransferase assay, using ovalbumin as a methyl acceptor as described above. The average specific activity of the group in each genotype is shown with error bars representing the standard error of the mean. The specific activity is measured in $\mathrm{pmol} / \mathrm{min}$ per $\mathrm{mg}$ protein in the red blood cell cytosolic extract. $\mathrm{Ile}_{119} / \mathrm{Ile}_{119}$ homozygotes are represented by triangles, $\mathrm{Ile}_{119} / \mathrm{Val}_{119}$ by circles, and $\mathrm{Val}_{11} / \mathrm{Val}_{119}$ by squares. C Methyltransferase stability under oxidative stress was measured in red blood cell cytosolic extracts of two representatives for each homozygous genotype. In three independent experiments, extracts were preincubated at either $0,7.7,30.8,76.9$, or $153.8 \mathrm{mM} \mathrm{H}_{2} \mathrm{O}_{2}$ with $1 \mathrm{mg} / \mathrm{ml}$ sodium azide for $15 \mathrm{~min}$ prior to the methyltransferase assay with ovalbumin. The specific activity given is measured relative to the activity maintained in the absence of $\mathrm{H}_{2} \mathrm{O}_{2}$. Error bars represent the standard error of the mean. $\mathrm{Ile}_{119}$ homozygous cytosols are represented by triangles; $\mathrm{Val}_{119}$ homozygous cytosols are represented by squares

\section{A. Specific Activity}

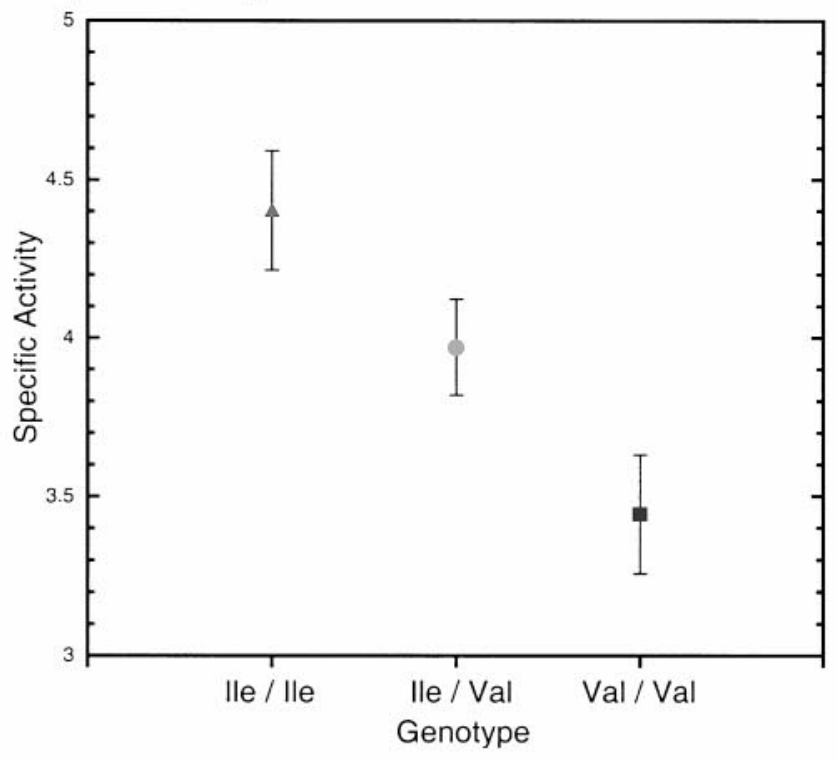

B. Temperature Stability
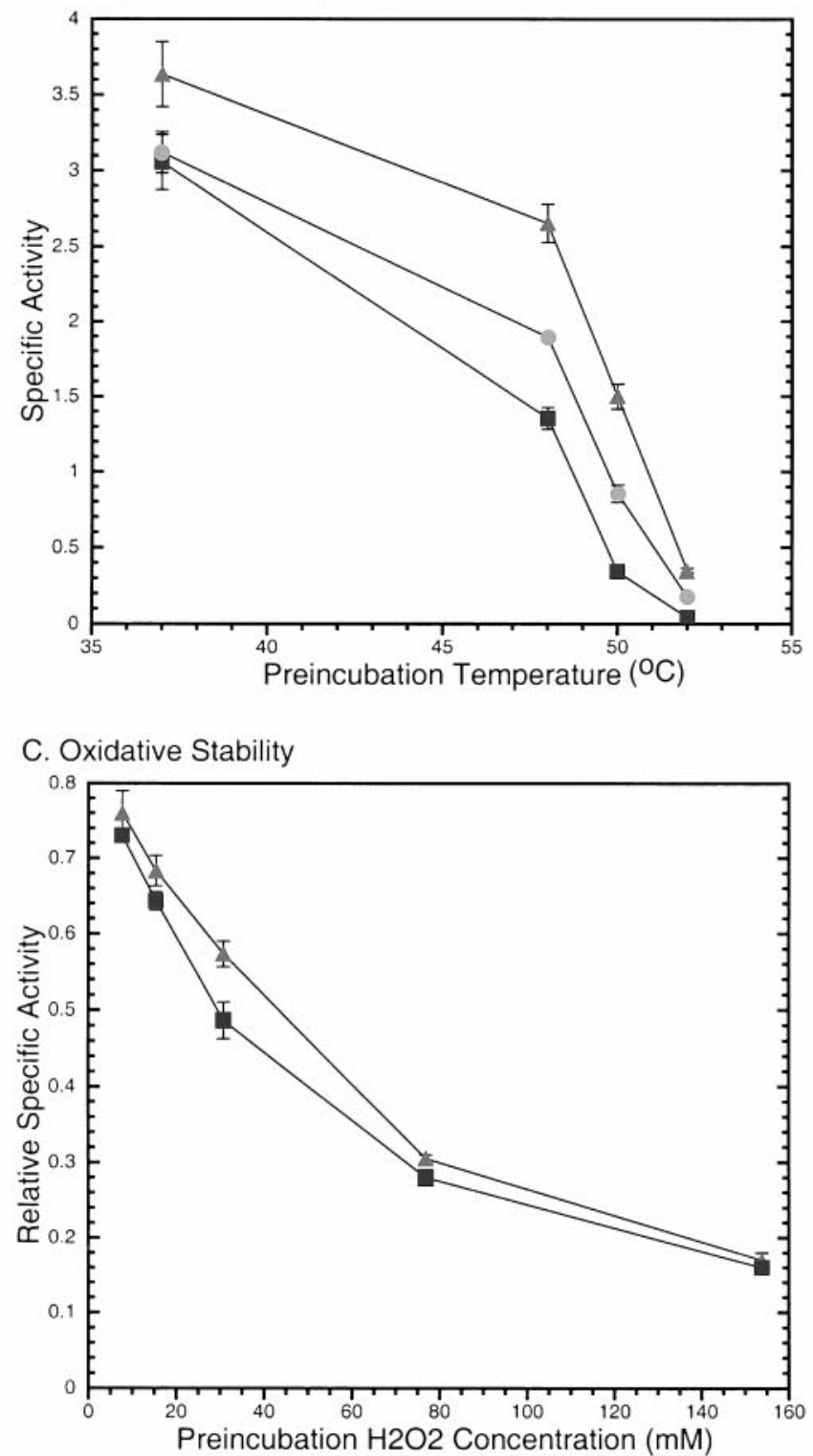
ence in the ability of either enzyme variant to recognize any of the representative peptide substrates (Fig. 4).

We next attempted to more accurately examine kinetic differences between the codon 119 variants with a range of substrate concentrations, using ovalbumin, two different isoaspartyl-containing peptides, and the brain cytosolic extract from a Pcmt-1-deficient mouse (Kim et al. 1997). The absence of the repair enzyme in these mice leads to the accumulation of proteins with damaged sites, particularly in the brain (Kim et al. 1997). Therefore, the Pcmt-1 deficient mouse strain was useful as a more representative source of endogenous methyl-accepting protein substrates in the damaged state. In three independent experiments, assays of red blood cell cytosolic extracts from representatives for each homozygous genotype $(n=3)$ using brain cytosol from Pcmt-1 deficient mice revealed a significant difference in both the $\mathrm{V}_{\max }$ and $\mathrm{K}_{\mathrm{m}}$ values between the $\mathrm{Ile}_{119}$ and $\mathrm{Val}_{119}$ polymorphic variants (Fig. 5A). The mean $\mathrm{V}_{\max }$ established for the $\mathrm{Ile}_{119}$ enzyme was $3.8( \pm 0.16 \mathrm{SEM}) \mathrm{pmol} / \mathrm{min}$ per $\mathrm{mg}$ protein, while the $\mathrm{Val}_{119}$ enzyme gave a mean value of 2.9 $( \pm 0.21 \mathrm{SEM}) \mathrm{pmol} / \mathrm{min}$ per $\mathrm{mg}$ protein $(P=0.004)$. This was consistent with the difference in specific activity observed with ovalbumin between these variants (Fig. 3A). Interestingly, the $\mathrm{K}_{\mathrm{m}}$ determined for the methyltransferase with the Pcmt-1 deficient mouse brain cytosol as a methylaccepting substrate was $1.9 \pm 0.19 \mathrm{mg} / \mathrm{ml}$ protein for the $\mathrm{Val}_{119}$ enzyme and $2.6 \pm 0.18 \mathrm{mg} / \mathrm{ml}$ protein for the $\mathrm{Ile}_{119}$ enzyme $(P=0.011)$. This difference represents a $30 \%$ increase in affinity of the $\mathrm{Val}_{119}$ enzyme for this collection of endogenous substrates. A difference between the amino acid 119 variants was also observed in kinetic experiments with ovalbumin (Fig. 5B). The $\mathrm{V}_{\max }$ values of ovalbumin for the $\mathrm{Ile}_{119}$ and $\mathrm{Val}_{119}$ homozygotes were significantly different, as expected, with values of $3.9 \pm 0.25 \mathrm{pmol} / \mathrm{min}$ per $\mathrm{mg}$ protein and $2.8 \pm 0.13 \mathrm{pmol} / \mathrm{min}$ per $\mathrm{mg}$ protein, respectively $(P=0.007)$. Affinity differences were also observed for ovalbumin, with the $\mathrm{K}_{\mathrm{m}}$ values of $3.4 \pm 0.38 \mathrm{mg} / \mathrm{ml}$ for the $\mathrm{Ile}_{119}$ enzyme and $2.3 \pm 0.35 \mathrm{mg} / \mathrm{ml}$ for the $\mathrm{Val}_{119}$ enzyme $(P=0.078)$. Again the $\mathrm{Val}_{119}$ enzyme showed an increase in affinity, although not quite meeting the $95 \%$ significance level. With respect to substrate affinity, no differences were observed for methyl-accepting peptides (Fig. 5C). The $\mathrm{V}_{\max }$ values established for the VYR(isoD)RR peptide were 3.7 $\pm 0.36 \mathrm{pmol} / \mathrm{min}$ per $\mathrm{mg}$ protein with the $\mathrm{Ile}_{119}$ cytosols and $3.2 \pm 0.38 \mathrm{pmol} / \mathrm{min}$ per $\mathrm{mg}$ protein with the $\mathrm{Val}_{119}$ cytosols (not significantly different; $P=0.37$ ). The $\mathrm{K}_{\mathrm{m}}$ values for the VYR(isoD)RR peptide were $17.5 \pm 1.5 \mu \mathrm{M}$ and $17.1 \pm$ $2.4 \mu \mathrm{M}$ for the $\mathrm{Ile}_{119}$ and $\mathrm{Val}_{119}$ cytosols, respectively (not significantly different; $P=0.90)$. The peptide YVS(isoD)GHG also had similar $\mathrm{K}_{\mathrm{m}}$ values with respect to the two isoforms (data not shown).

Protein L-isoaspartate (D-aspartate) methyltransferase alleles in successful longevity

Because the potential accumulation of damaged proteins may have detrimental effects over the human lifespan, an analysis of a group of "successfully aged" individuals was

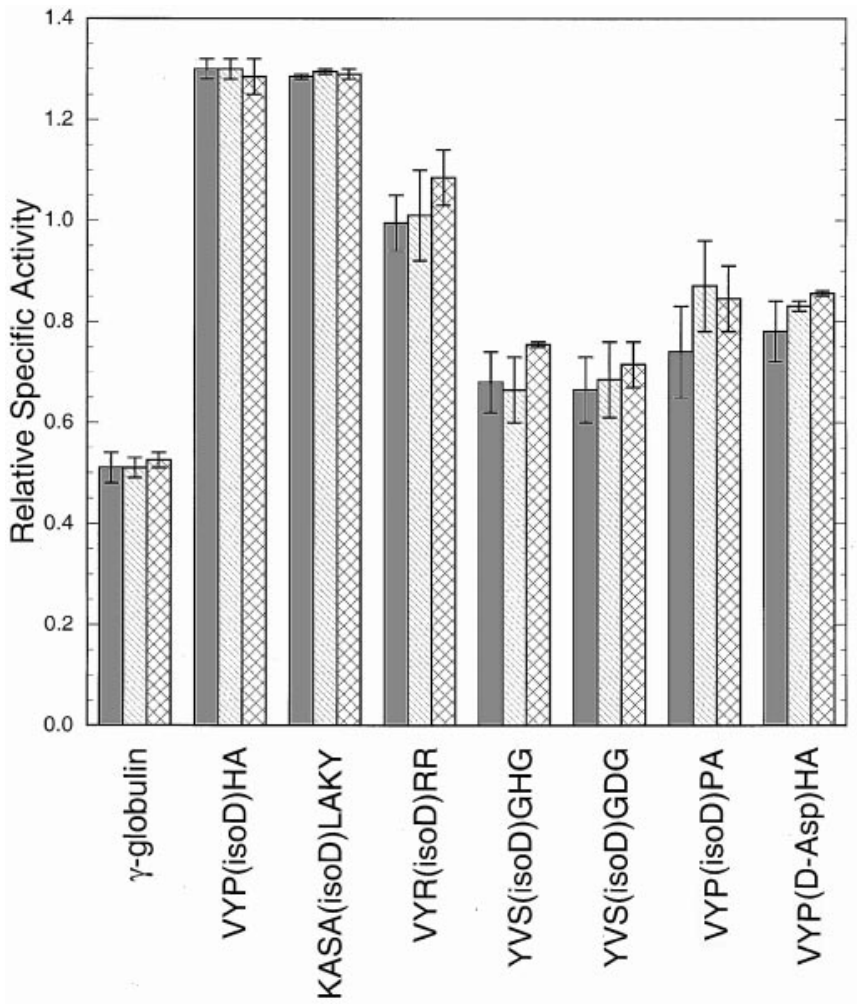

Fig. 4. Methyl-acceptor substrate specificity comparisons between the PCMT1 amino acid 119 polymorphic variants, using various protein and peptide substrates. Red blood cell cytosols from a homozygous $\mathrm{Ile}_{119}$ individual (solid bars), a heterozygous $\mathrm{Ile}_{119} / \mathrm{Val}_{119}$ individual (striped bars), and a homozygous $\mathrm{Val}_{119}$ individual (cross-hatched bars), were assayed in two independent experiments for methyltransferase activity. The following concentrations were used for each

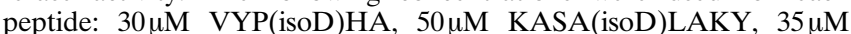
VYR(isoD)RR, $155 \mu \mathrm{M}$ YVS(isoD)GHG, $4.89 \mathrm{mM}$ YVS(isoD)GDG, $40 \mathrm{mM}$ VYP(isoD)PA, and $30 \mathrm{mM}$ VYP(D-Asp)HA. These concentrations are roughly ten fold greater than the $\mathrm{K}_{\mathrm{m}}$ for these peptides, except for YVP(isoD)HA and KASA(isoD)LAKY, for which 100-fold concentration was used. The specific activity given is measured relative to ovalbumin at $\mathrm{V}_{\max }$ concentrations of substrate to normalize for isoform stability differences. Error bars represent the standard error of the mean

initiated, with the assumption that this population might be enriched in the most beneficial alleles (including those of the PCMT1 methyltransferase) for a long and healthy life. A preliminary study was carried out with 40 individuals of Ashkenazi Jewish descent that met our "successfully aged" phenotype by being age 75 or older and in good mental and physical health. The 40 healthy older individuals in this study ranged in age from 75-104, with an average age of 87.2 years, and were compared with a younger control population of the same ethnic background consisting of 40 individuals ranging in age from $21-74$, and averaging 36.2 years. We found that the overall allele frequencies were nearly identical between the two groups and very similar to the expected values for the Caucasian ethnic background (Table 3). Surprisingly, however, the distribution of genotypes revealed that, within the older population, the heterozygous genotype was represented at an unusually high frequency of $65 \%$, given the $45 \%$ frequency in ethnically 

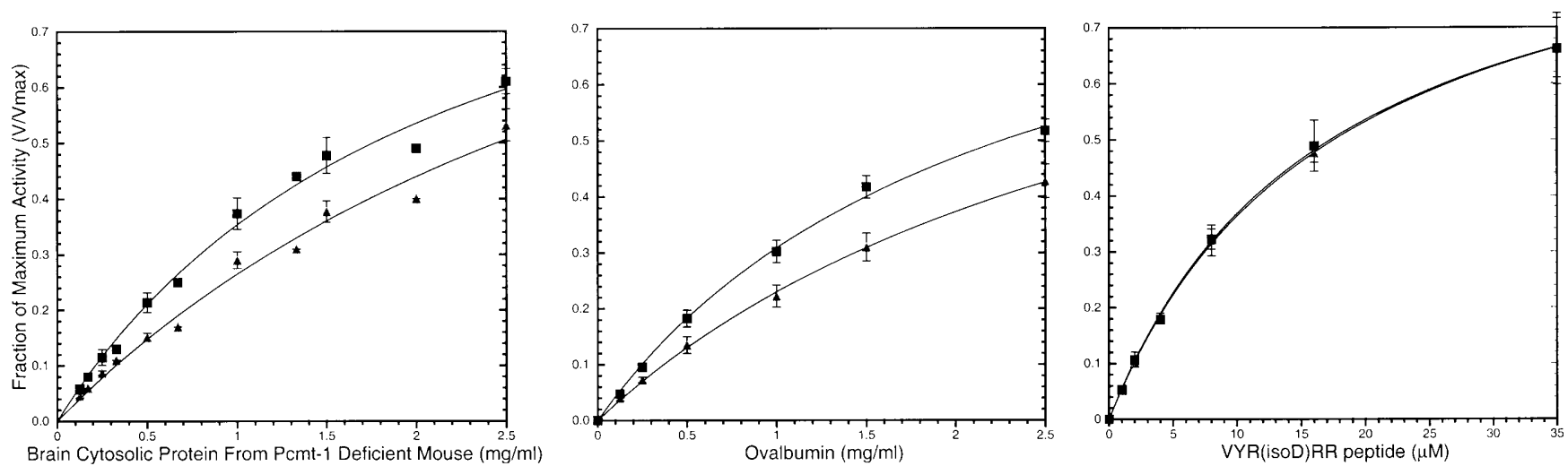

Fig. 5A-C. Kinetic analysis of methyltransferase enzyme activity in the amino acid 119 polymorphic variants. In three independent experiments, red blood cell cytosols from three unrelated representatives of each homozygous genotype ( $\left.\mathrm{Ile}_{119} / \mathrm{Ile}_{119} ; \mathrm{Val}_{119} / \mathrm{Val}_{119}\right)$ were used in enzymatic assays with three different methyl-accepting substrates. A brain cytosolic extract from a Pcmt-1 deficient mouse; B ovalbumin; $\mathbf{C}$ L-isoaspartyl-containing synthetic peptide. The specific methyltransferse activity is shown as a fraction of the maximum rate to normalize the $\mathrm{V}_{\max }$ differences associated with $\mathrm{Ile}_{119}$ and $\mathrm{Val}_{119}$ genotypes.

Squares represent data from $\mathrm{Val}_{119} / \mathrm{Val}_{119}$ homozygous individuals; triangles represent data from individuals homozygous for the $\mathrm{Ile}_{119}$-containing enzyme. The solid lines are drawn based on the best fit of the Michaelis-Menton equation to the data yielding $\mathrm{K}_{\mathrm{m}}$ values of $1.9 \pm$ $0.19 \mathrm{mg} / \mathrm{ml}\left(\mathrm{Val}_{119}\right)$ and $2.6 \pm 0.18 \mathrm{mg} / \mathrm{ml}\left(\mathrm{Ile}_{119}\right)$ for brain cytosolic protein, $2.3 \pm 0.35 \mathrm{mg} / \mathrm{ml}\left(\mathrm{Val}_{119}\right)$ and $3.4 \pm 0.38 \mathrm{mg} / \mathrm{ml}\left(\mathrm{Ile}_{119}\right)$ for ovalbumin, and $17.1 \pm 2.4 \mu \mathrm{M}\left(\mathrm{Val}_{119}\right)$ and $17.5 \pm 1.5 \mu \mathrm{M}\left(\mathrm{Ile}_{119}\right)$ for the synthetic peptide VYR(isoD)RR. Error bars represent the standard error of the mean

Table 3. Polymorphism in younger and older Ashkenazi Jewish populations

Younger Ashkenazi Jewish (Average age, 36.2 years; range, 21-74 years)
Healthy older Ashkenazi Jewish (Average age, 87.2 years; range, $75-104$ years)

\begin{tabular}{clllcrcr}
\hline Ile/Ile & Ile/Val & Val/Val & & Ile/Ile & Ile/Val & Val/Val \\
\cline { 5 - 7 } 9 & 18 & 13 & No. of individuals & 6 & 26 \\
36 & & 44 & No. of alleles & 38 & 8 \\
0.450 & 0.550 & Observed allele frequency & 0.475 & 42 \\
0.203 & 0.495 & 0.303 & Expected Hardy-Weinberg distribution & 0.226 & 0.499 \\
0.225 & 0.450 & 0.325 & Observed population distribution & 0.150 & 0.650 \\
\hline
\end{tabular}

matched younger controls. While comparison of the two populations directly did not reveal statistical significance at the $P<0.05$ level $(P=0.20)$, a significant difference was observed when the genotype frequencies in the old population were compared with the population frequencies expected by Hardy-Weinberg equilibrium based on the allele frequencies observed in the younger population $(P=0.049)$. This result suggests the possibility of a heterozygote advantage and that a selection for having both forms of the gene may occur for individuals that have "successfully aged", but further studies will be needed to validate this hypothesis. This putative hybrid vigor may offer a protective advantage for the $\mathrm{Ile}_{119} / \mathrm{Val}_{119}$ genotype in the repair of protein damage associated with aging.

Additional polymorphisms identified in the human PCMT1 gene

To determine whether additional polymorphisms in the PCMT1 gene exist, a comprehensive screen of the entire coding region was undertaken. Fifty randomly chosen individuals of various ethnic backgrounds were genotyped by PCR-SSCP with primer sets specific for each of the seven major coding exons and flanking intron sequence of the gene (DeVry et al. 1996) (Table 1). Using the two different gel electrophoresis conditions described in the "Materials and Methods" section, three additional polymorphisms were identified, but all were located in noncoding regions of the gene (Fig. 6). A single nucleotide substitution was identified in intron 4, 79bp upstream of exon 5, with a T-to-C transition base substitution. An insertion/deletion of a $\mathrm{T}$ nucleotide was identified in intron 6 in a region of 12 sequential T nucleotides, $8-19 \mathrm{bp}$ upstream of exon 7 . In the $3^{\prime}$-untranslated region ( $3^{\prime}$-UTR), a GT dinucleotide repeat was observed approximately $2 \mathrm{~kb}$ downstream of exon 8 , with repeat length variation limited to either 8 or 14 repeats. Interestingly, all three of these noncoding polymorphisms demonstrate nonrandom association with the Ile/Val polymorphism at amino acid position 119, resulting in just two different haplotypes being present (Fig. 7). Although the genotyping at the non-coding polymorphic sites initially comprised 50 individuals, further attempts to find a recombination event involved genotyping additional individuals at the site most distant to the $\mathrm{Ile}_{119} / \mathrm{Val}_{119}$ polymorphism, the $3^{\prime}$-UTR dinucleotide repeat. A total of 122 individuals (39 $\mathrm{Ile}_{119}$ homozygotes, $27 \mathrm{Val}_{119}$ homozygotes, and $56 \mathrm{Ile}_{119} /$ $\mathrm{Val}_{119}$ heterozygotes) have subsequently been genotyped at 
both of these two loci, separated by almost $20 \mathrm{~kb}$, and no recombinants have been identified, demonstrating complete linkage disequilibrium.

An additional base substitution was observed in intron 2 for a single individual out of the 50 genotyped in the polymorphism screen described above (Fig. 8A). However, analysis of an additional 50 individuals revealed no further cases of this mutation. Sequencing the PCR product in this individual revealed a mutation upstream of exon 3 in the branch site consensus splicing sequence (Fig. 8B). The genotype at this position for the individual was heterozygous with a C-to-A transversion in one copy of the gene. We then genotyped 17 additional members of this individual's family (Fig. 8C). We found five more cases of the mutation in a heterozygous genotype that followed a Mendelian pattern of inheritance through three generations (Fig. 8C). However, enzymatic analysis of the red blood cells from a heterozygous individual revealed no differences in the level of repair methyltransferase activity (data not shown), suggesting little, if any, effect of this mutation on enzyme expression.

Finally, the variation in the coding region of exon 7 identified by Tsai and Clarke (1994), that apparently resulted in an Arg residue at amino acid position 205, was not observed in 50 individuals genotyped, nor could it be con-

Fig. 6A-C. Additional polymornoncoding regions of the $P C M T 1$ gene. PCR-SSCP analysis of the entire coding region and flanking intronic sequence revealed three newly identified polymorphisms. The PAGE banding pattern of the SSCP for each polymorphism is shown on the left and the descriptive sequence analysis for the homozygous individuals singled out is shown to the right. A Intron 4 contains a single nucleotide transition polymorphism that is underlined. B Intron 6 contains a single nucleotide insertion/deletion polymorphism resulting in a repeated stretch of either 11 or $12 \mathrm{~T}$ residues. $\mathbf{C}$ The $3^{\prime}$-untranslated region $(U T R)$ contains a biallelic dinucleotide repeat of either 14 or $8 \mathrm{GT}$ residues. The sequence data given are representative of the reverse strand for the intron 4 and intron 6 polymorphisms, but the template strand sequence is shown for the 3'-UTR polymorphism

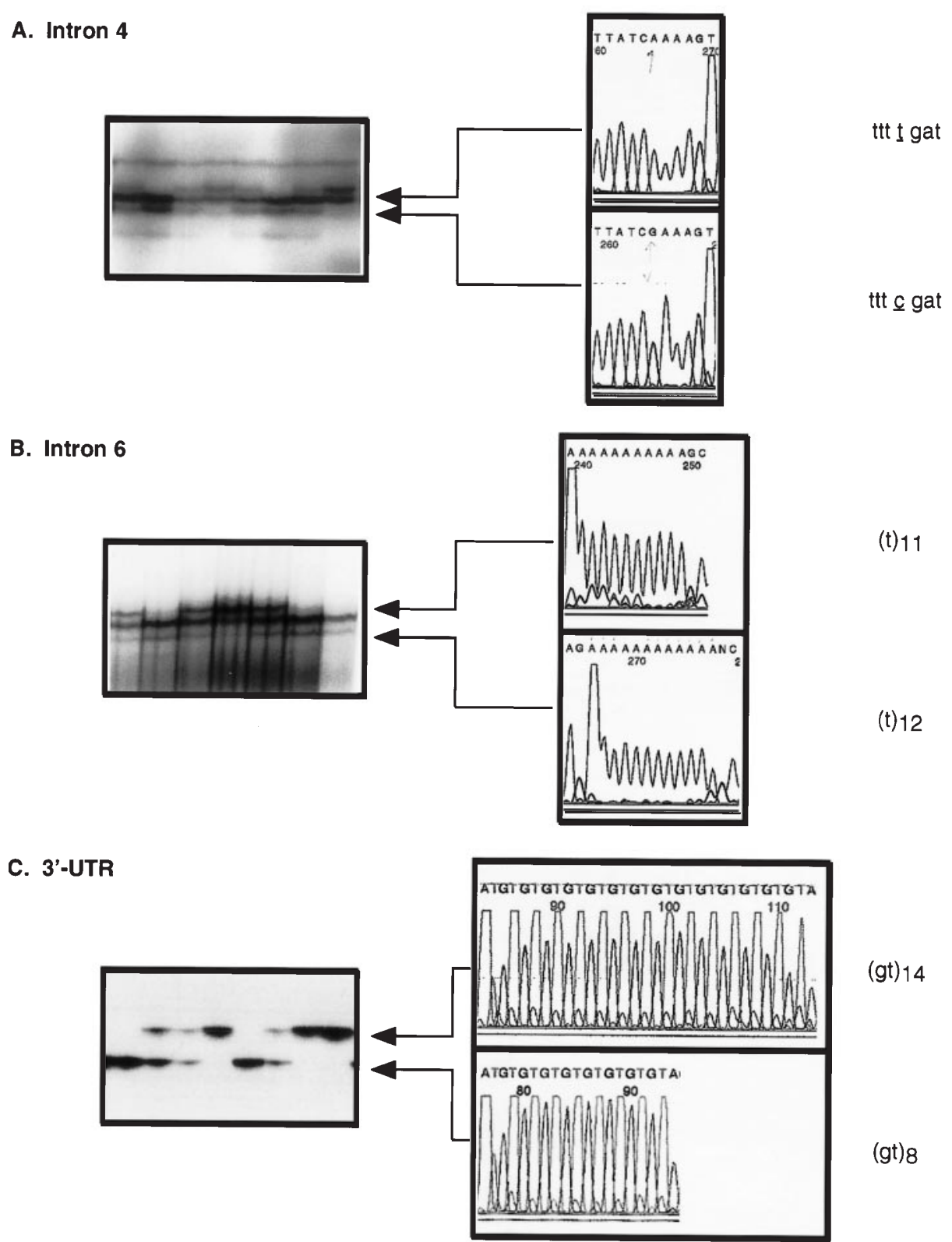




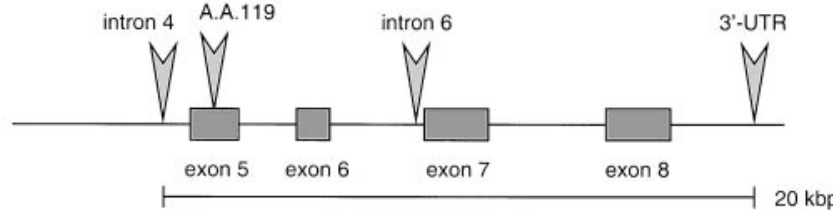

Haplotypes

\begin{tabular}{lllll} 
I. & t & A (lle) & - & (gt)8 \\
\cline { 2 - 5 } II. & c & G (Val) & $t$ & (gt)14 \\
& & &
\end{tabular}

Fig. 7. Four identified polymorphisms of the PCMT1 gene demonstrate complete linkage disequilibrium. Each allele associates with a specific set of alleles at the other polymorphic loci. The nonrandom association pattern is illustrated by the presence of only two types of chromosomes. The position of these polymorphisms relative to one another is depicted with arrowheads, over a distance spanning approximately $20 \mathrm{~kb}$. A total of 122 individuals have been genotyped at both the $\mathrm{Ile}_{119} / \mathrm{Val}_{119}$ and $3^{\prime}$-UTR dinucleotide repeat polymorphisms without a single recombination event being identified

firmed for the individual in which it was originally identified (data not shown). In addition, the Ile/Leu variation at amino acid position 22, originally seen by protein sequence analysis in Ingrosso et al. (1989), was not identified in the 50 individuals genotyped in our experiments.

\section{Discussion}

The Ile/Val polymorphism at codon 119 in the protein Lisoaspartate (D-aspartate) methyltransferase is the only amino acid substitution in this enzyme that occurs with any appreciable frequency, as determined in this comprehensive screen of the entire coding sequence by PCR-SSCP analysis. We show here that the allele frequencies for these codon 119 variants differ between ethnic groups and that phenotypic differences are observed in both enzyme thermostability and substrate affinity. While the $\mathrm{Ile}_{119}$ isoform is a more stable enzyme, as determined by thermotolerance, the $\mathrm{Val}_{119}$ isoform has a higher affinity for protein substrates. These compensatory attributes observed in vitro are consistent with our findings of a possible association between "successful aging" and selection of the heterozygous genotype at amino acid position 119.

The activity differences observed between the polymorphic isoforms of this methyltransferase are subtle but significant, as might be expected from such a conserved amino acid substitution. The higher thermostability of the $\mathrm{Ile}_{119}$ enzyme may result in a greater amount of functional enzyme in red blood cell cytosols of individuals homozygous for that genotype as compared with those from $\mathrm{Val}_{119}$ homozygotes. The consistently higher enzyme activity and thermostability observed in multiple individuals of the same genotype would indicate that it is not merely a difference in enzyme expression levels. Moreover, our data are in agreement with results observed by David et al. (1997) in both parameters of activity and stability. Stabil-ity at high tem- peratures and oxidative stress may reflect greater stability under physiologically stressful conditions. The novel difference in substrate affinity between the amino acid 119 variants may balance out these stability differences. Interestingly, the affinity differences are specific for protein substrates, and are not seen in the small methyl-accepting peptide substrates. Although the structure for the Lisoaspartyl methyltransferase has yet to be determined, comparisons with other AdoMet-binding methyltransferases suggest that this polymorphic region may be in the same planar face as the active site. The presence of an additional methyl group in the isoleucine side chain could possibly contribute a small amount of steric hindrance at the substrate-interacting surface. This may explain the affinity differences observed between the $\mathrm{Ile}_{119} / \mathrm{Val}_{119}$ variants of the repair methyltransferase for protein but not peptide substrates. Previous studies have demonstrated that the accumulation rate of damaged proteins is inversely proportional to the substrate affinity of the methyltransferase (Lowenson and Clarke 1991). In mathematical models of a typical erythrocyte protein, it was shown that, after 120 days, the number of damaged sites decreased almost linearly as the $\mathrm{K}_{\mathrm{m}}$ for methylation decreased. Therefore, a $30 \%$ difference in substrate affinity between the $\mathrm{Ile}_{119}$ and $\mathrm{Val}_{119}$ isoforms of the methyltransferase (Fig. 5) could account for a substantial difference in the level of isoaspartyl damage accumulation.

The idea that protein repair may play a role in the multifaceted process of aging led us to search for a possible selection with the $\mathrm{Ile}_{119} / \mathrm{Val}_{119}$ polymorphism in a healthy old population, similar to other studies on the genetics of longevity (Schachter et al. 1994; Mannucci et al. 1997). The initial findings for a small Ashkenazi Jewish population indicate a possible selection for the heterozygous genotype in the "successfully-aged" individuals, suggesting a putative hybrid vigor. This would correlate with our findings on the compensatory benefits of higher activity/stability in the $\mathrm{Ile}_{119}$ enzyme and higher substrate affinity in the $\mathrm{Val}_{119}$ enzyme. Thus, the combination of a higher stability and a higher affinity enzyme in the heterozygous individual may be most advantageous for preventing the accumulation of damaged proteins and mitigating the aging process. We are currently acquiring DNA samples from a group of Japanese individuals also meeting our "successfully-aged" requirements to see if they corroborate our previous findings in the Jewish population. The skewed allele frequency in the Asian population should make a heterozygote selection even more pronounced if the hybrid vigor hypothesis is correct.

The ethnic differences in allele frequencies for the $\mathrm{Ile}_{119} /$ $\mathrm{Val}_{119}$ polymorphism were significant between some of the populations for which there were adequate numbers to compare. The high allele frequency for the $\mathrm{Ile}_{119}$ enzyme in the African and Asian populations (0.81 and 0.88, respectively) is suggestive of these populations being nearly homogeneous for this isoform of PCMT1. The rare presence of the $\mathrm{Val}_{119}$ allele in these populations, in which no $\mathrm{Val}_{119} /$ $\mathrm{Val}_{119}$ homozygotes were identified, may simply reflect admixture in the lineages of our representatives. This is a strong possibility, considering that most of our participants 
Fig. 8A-C. Mutation identified within the branch site consensus sequence upstream of exon 3 in the PCMT1 gene. A Normal banding pattern (lanes 1-4) and alternative banding pattern (lane 5) observed for exon 3 by SSCP analysis in 5 individuals out of 100 genotyped. Sequencing of the reverse strand of exon 3 in this individual (in lane 5) revealed a heterozygous genotype with a $\mathrm{C}$-toA transversion in one copy of the PCMT1 gene. The template strand sequence for branch site is given at the right for the DNA of the individual in lane 5 (below) and for the normal DNA samples (above). Lane 6 of the SSCP gel represents a negative control. B Sequence of exon 3 and flanking introns. Lowercase lettering represents intronic sequence and uppercase lettering represents exon sequence. Primers used in PCR-SSCP and sequencing are boxed. Amino acids encoded by exon 3 are depicted below the exon sequence. The underlined sequence identifies the branch site splicing sequence motif compared with the consensus sequence identified by Green (1991). C Analysis of the branch site mutation in family members of the individual identified with the exon 3 mutation above. PCR-SSCP analysis of numbered individuals revealed a Mendelian inheritance pattern. The propositus is individual number 56 (arrow and bold). Only heterozygotes of the $\mathrm{C} \rightarrow \mathrm{A}$ branch site mutation were observed in this family (individuals with striped symbols). Circles represent females and squares represent males
A.
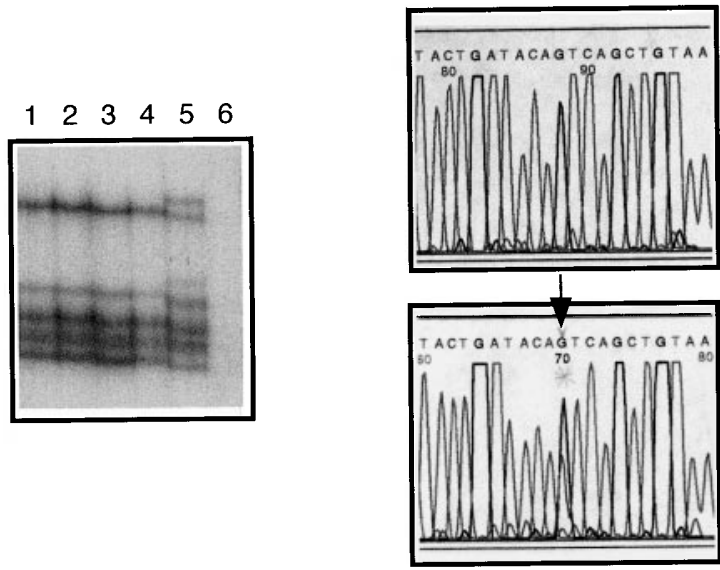

agctgac

(lanes 1-4)

$\underset{\mathrm{agctga}}{\mathrm{c}}$

(lane 5)

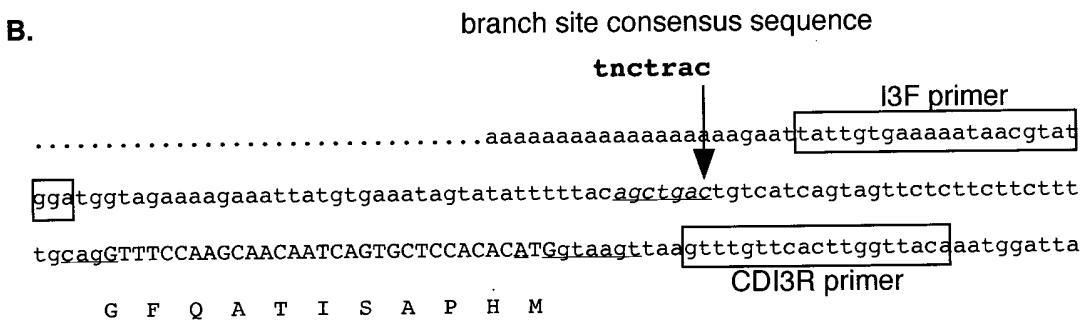

cattttctctataatcattttctttactaaaaagatttaaagaaagttgtatcaatttatcact......

c.

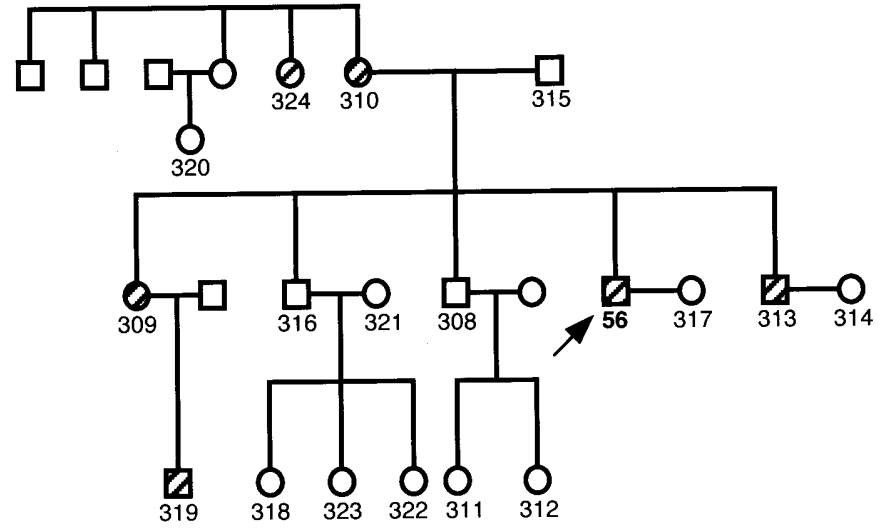

are North American, and dilution of ancestral gene pools is common in this group (Chakraborty et al. 1992). In sharp contrast, the $\mathrm{Val}_{119}$ allele appears to be quite well established in the Caucasian population. This geographic distribution might suggest that the $\mathrm{Val}_{119}$ allele was a mutation derived from the original $\mathrm{Ile}_{119}$ allele, based on the evolutionary expansion of modern humans out of Africa 100,000 years ago (Cavalli-Sforza et al. 1994). If the mutational event has not spread to Asia this would suggest that it was not yet present in the population when Paleolithic humans moved westward into Europe and eastward into Asia 35,000-40,000 years ago (Cavalli-Sforza et al. 1994). Alternatively, a founder effect may have contributed to this large discrepancy in allele frequencies, but any selective effects for maintaining the even distribution in the Caucasian population remain to be determined. The genotyping of more individuals from other races, particularly genetically homogeneous peoples from different parts of the world, may enable us to more accurately hypothesize about the origin, evolution, and dispersion of this polymorphism.

Our findings here can be compared to the situation seen with the human catechol O-methyltransferase (COMT) (Weinshilboum 1992; Lotta et al. 1995). A valine-to-methionine substitution at codon 108 in COMT results in a high and low activity enzyme, respectively. Similar to the Lisoaspartyl methyltransferase, this activity difference may be attributable to differences in thermostability. Interestingly, the ethnic differences in allele frequency seem to 
parallel our findings as well, with the low-activity allele being more prevalent in the Caucasian population as compared with Asian and African populations (McLeod et al. 1998). The availability of a three-dimensional structure of rat COMT (Vidgren et al. 1994), coupled with the conservation of sequence motifs between S-adenosylmethionine-utilizing methyltransferases, led us to ask whether the PCMT1 polymorphic site at codon 119 was located in a similar position to the COMT polymorphic site. Alignment of the PCMT1 and COMT sequences showed that both the PCMT1 and COMT polymorphic sites appearred to be located in a loop connecting the putative S-adenosylmethionine-binding sequences of motif post I and II (Kagan et al. 1997).

The physiological importance of such a thermostability change in an enzyme has been demonstrated most dramatically in the methylene tetrahydrofolate reductase (van der Put et al. 1996), in which an alanine for valine substitution results in decreased folate metabolism, elevated homocysteine levels, and a significant risk for having spina bifida offspring. In the case of PCMT1 however, we find a compensating increase in affinity of the more thermolabile enzyme.

The identification of three additional polymorphisms is not unexpected considering that approximately $2400 \mathrm{bp}$ of sequence was screened in our analysis, with approximately one polymorphic site expected per 500 nucleotides of DNA sequence (Cavalli-Sforza et al. 1994). However, it was surprising to find complete allelic association at all four sites, demonstrating that these four different polymorphisms were in total linkage disequilibrium. Although some degree of linkage disequilibrium is common (Antonarakis et al. 1988; Heizmann et al. 1991) we have found no evidence at all for recombination within this $20-\mathrm{kb}$ region of the PCMT1 gene. Based on the assumption that $1 \mathrm{Mb}$ is equal to $1 \mathrm{cM}$, we would have expected a $0.02 \%$ recombination rate per generation over this segment of DNA. In the 66 homozygous individuals (132 chromosomes) that were genotyped at both the codon 119 and $3^{\prime}$-UTR polymorphic sites we would thus expect one recombination event each 38 generations. An estimate of 25 years per generation would put this expected recombination frequency at 1 every 950 years. The absence of recombination would suggest that either the emergence of this haplotype occurred recently (Stephens et al. 1998) or that the PCMT1 gene is located in a recombination "cold-spot" of the chromosome.

We are also interested in addressing questions about the nature of selective forces that underlie this variation and allow it to be maintained in such an evolutionarily conserved enzyme (Kagan et al. 1997). New mutations can establish polymorphism in a population by the processes of natural selection and random genetic drift. A new mutation that is maintained by natural selection must eventually take over the entire population, establishing homozygosity for the mutation (Falconer 1989). The more recent origin of the Val allele, as predicted by the geographic distribution of allele frequencies, could be in the process of establishing itself in such a way within the European population. That is, the allele frequencies we are currently observing might possibly be a transitional stage. Alternatively, a balanced polymorphism can become established in a population if the heterozygote has a greater fitness than either homozygote (Falconer 1989). Although it is often difficult to measure fitness differences for most single-locus polymorphisms, we have attempted to draw some conclusions about fitness based on phenotypic differences in methyltransferase repair activity. The compensating benefits of the Ile $_{119}$ stability and the $\mathrm{Val}_{119}$ affinity could possibly fulfill requirements for maintaining a selection for heterozygotes, but the effect this would have on fitness is still unknown.

Acknowledgments We would like to thank Vinay Bhaskar, Dr. Mary Beth Mudgett, and all the Clarke lab members for help in recruiting, collecting, and donating DNA and blood samples. We are also grateful for the cooperation of Dr. Jack Schnelle, Helane Hartman, and Judy Aronson in obtaining the "successfully-aged" DNA samples at the Boron Center for Gerontological Research and the Jewish Home for the Aging in Reseda, California. Dr. Richard Weinshilboum was also kind enough to provide us with additional DNA samples. Finally, we appreciate the efforts of Bill Tsai in the initial work on the polymorphisms of PCMT1, Dr. Jake Lusis for his critical reading of this manuscript, and Dr. David Solomon for his helpful advice.

This work was supported by Grant GM 26020 from the National Institutes of Health and a scholarship to C.G.D. from the Glenn Foundation and the American Federation for Aging Research.

\section{References}

Antonarakis SE, Oettgen P, Chakravarti A, Halloran SL, Hudson RR, Feisee L, Karathanasis SK (1988) DNA polymorphism haplotypes of the human apolipoprotein APOA1-APOC3-APOA4 gene cluster. Hum Genet 80:265-273

Bailey A (1995) Single-stranded conformational polymorphisms. In: Innis MA, Gelfand DH, Sninsky JJ (eds) PCR strategies. Academic, San Diego, pp 121-129

Bailey JL (1967) Techniques in protein chemistry. Elsevier, New York Bartosz G (1990) Blood cell biochemistry: erythroid cells. Plenum, New York

Brennan TV, Anderson JW, Jia Z, Waygood EB, Clarke S (1994) Repair of spontaneously deamidated HPr phosphocarrier protein catalyzed by the L-isoaspartate (D-aspartate) O-methyltransferase. J Biol Chem 269:24586-24595

Cavalli-Sforza LL, Menozzi P, Piazza A (1994) The history and geography of human genes. Princeton University Press, Princeton, NJ

Chakraborty R, Kamboh MI, Nwankwo M, Ferrell RE (1992) Caucasian genes in American blacks: new data. Am J Hum Genet 50:145-155

Clarke S (1999) A protein carboxyl methyltransferase that recognizes age-damaged peptides and proteins and participates in their repair. In: Cheng X, Blumenthal RM (eds) Structure and function of Sadenosylmethionine-dependent Methyltransferases. World Scientific Publishing/Imperial College Press, Singapore

David CL, Szumlanski CL, DeVry CG, Park-Hah JO, Clarke S, Weinshilboum RM, Aswad DW (1997) Human erythrocyte protein L-isoaspartyl methyltransferase: heritablility of basal activity and genetic polymorphism for thermal stability. Arch Biochem Biophys 346:277-286

DeVry CG, Clarke S (1999) Assignment of the protein L-isoaspartate (D-aspartate) $O$-methyltransferase gene (PCMT1) to human chromosome bands 6q24-q25 with radiation hybrid mapping. Cytogenet Cell Genet 84:130-131

DeVry CG, Tsai W, Clarke S (1996) Structure of the human gene encoding the protein repair L-isoaspartyl (D-aspartyl) Omethyltransferase. Arch Biochem Biophys 335:321-332

Falconer DS (1996) Introduction to quantitative genetics. Longman Scientific and Technical, Essex, England

Frosst R, Blom HJ, Milos R, Goyette P, Sheppard CA, Matthews RG, Boers GJH, (1995) A candidate genetic risk factor for vascular disease: a common mutation in methylenetetrahydrofolate reductase. Nature Genet 10:111-113 
Geiger T, Clarke S, den Heijer M, Kluijtmans LAJ, van den Hauvel LP, Rozen R (1987) Deamidation, isomerization, and racemization at asparaginyl and aspartyl residues in peptides. J Biol Chem 262:785-794

Green MR (1991) Biochemical mechanism of constitutive and regulated pre-mRNA splicing. Annu. Rev. Cell Biol. 7:559-599

Harding JJ, Beswick HT, Ajiboye R, Huby R, Blakytny R, Rixon KC (1989) Non-enzymic post-translational modification of proteins in aging. A review. Mech Ageing Dev 50:7-16

Heizmann C, Kirchgessner T, Kwiterovich PO, Ladias JA, Derby C, Antonarakis SE, Lusis A (1991) DNA polymorphism haplotypes of the human lipoprotein lipase gene: possible association with high density lipoprotein levels. Hum Genet 86:578-584

Ingrosso D, Fowler AV, Bleibaum J, Clarke S (1989) Sequence of the D-aspartyl/L-isoaspartyl protein methyltransferase from human erythrocytes. J Biol Chem 264:20131-20139

Johnson BA, Langmack EL, Aswad DW (1987a) Partial repair of deamidation-damaged calmodulin by protein carboxyl methyltransferase. J Biol Chem 262:12283-12287

Johnson BA, Murray EDJ, Clarke S, Glass DB, Aswad DW (1987b) Protein carboxyl methyltransferase facilitates conversion of atypical L-isoaspartyl peptides to normal L-aspartyl peptides. J Biol Chem 262:855-866

Kagan RM, McFadden HJ, McFadden PN, O'Connor C, Clarke S (1997) Molecular phylogenetics of a protein repair methyltransferase. Comp Biochem Physiol 117B:379-385

Kim E, Lowenson JD, MacLaren DC, Clarke S, Young SG (1997) Deficiency of a protein-repair enzyme results in the accumulation of altered proteins, retardation of growth, and fatal seizures in mice. Proc Natl Acad Sci USA 94:6132-6137

Litt M, Hauge X, Sharma V (1993) Shadow bands seen when typing polymorphic dinucleotide repeats: some causes and cures. BioTechniques 15:280-284

Lotta T, Vidgren J, Tilgmann C, Ulmanen I, Melen K, Julkunen I, Taskinen J (1995) Kinetics of human soluble and membrane-bound catechol O-methyltransferase: a revised mechanism and description of the thermolabile variant of the enzyme. Biochemistry 34:4202-4210

Lowenson JD, Clarke S (1991) Structural elements affecting the recognition of L-isoaspartyl residues by the L-isoaspartyl/D-aspartyl protein methyltransferase. J Biol Chem 266:19396-19406

Lowenson JD, Clarke S (1995) Recognition of isomerized and racemized aspartyl residues in peptides by the protein L-isoaspartate (Daspartate) $O$-methyltransferase. In: Aswad DW (ed) Deamidation and isoaspartate formation in peptides and proteins. CRC Press, Boca Raton, FL, pp 47-64

Macfarlane DE (1984) Inhibitors of cyclic nucleotide phosphodiesterases inhibit protein carboxyl methylation in intact blood platelets. J Biol Chem 259:1357-1362

MacLaren DC, Kagan RM, Clarke S (1992a) Alternative splicing of the human isoaspartyl protein carboxyl methyltransferase RNA leads to the generation of a c-terminal -RDEL sequence in isozyme II. Biochem Biophys Res Commun 185:277-283

MacLaren DC, O'Connor CM, Xia Y-R, Mehrabian M, Klisak I, Sparkes RS, Clarke S, Lusis AJ (1992b) The L-isoaspartyl/D-aspartyl protein methyltransferase gene (pcmt1) maps to human chromosome $6 \mathrm{q} 22.3-6 \mathrm{q} 24$ and the syntenic region of mouse chromosome 10. Genomics 14:852-856
Mannucci PM, Mari D, Merati G, Peyvandi F, Tagliabue L, Sacchi E, Taioli E, Sansoni P, Bertolini S, Francesci C (1997) Gene polymorphisms predicting high plasma levels of coagulation and fibrinolysis protein: a study in centenarians. Arterioscler Thromb Vasc Biol 17:755-759

McFadden PN, Clarke S (1986) Protein carboxyl methyltransferase and methyl acceptor proteins in aging and cataractous tissue of the human eye lens. Mech Ageing Dev 34:91-105

McFadden PN, Clarke S (1987) Conversion of isoaspartyl peptides to normal peptides: implications for the cellular repair of damaged proteins. Proc Natl Acad Sci USA 84:2595-2599

McLeod HL, Syvanen AC, Githang'a J, Indalo A, Ismail D, Dewar K, Ulmanen I, Sludden J (1998) Ethnic differences in catechol Omethyltransferase pharmacogenetics: frequency of the codon 108/ 158 low activity allele is lower in Kenyan than Caucasian or Southwest Asian individuals. Pharmacogenetics 8:195-199

Patel K, Borchardt RT (1990) Chemical pathways of peptide degradation. II. Kinetics of deamidation of an asparaginyl residue in a model hexapeptide. Pharm Res 7:703-711

Potter SM, Henzel WJ, Aswad DW (1993) In vitro aging of calmodulin generates isoaspartate at multiple Asn-Gly and Asp-Gly sites in calcium-binding domains II, III, and IV. Protein Sci 2:1648-1663

Richards B, Skoletsky J, Shuber AP, Balfour R, Stern RC, Dorkin HL, Parad RB, Witt D, Klinger KW (1993) Multiplex PCR amplification from the CFTR gene using DNA prepared from Buccal brushes/ swabs. Hum. Mol.Genetics 2:159-163

Roher AE, Lowenson JL, Clarke S, Wolkow C, Wang R, Cotter RJ, Reardon IM, Zurcher-Neely HA, Heinrickson RL, Ball MJ, Greenberg BD (1993) Structural alterations in the peptide backbone of $\beta$-amyloid core protein may account for its deposition and stability in Alzheimer's disease. J Biol Chem 268:3072-3083

Schachter F, Faure-Delanef L, Guenot F, Rouger H, Froguel P, Lesueur-Ginot L, Cohen D (1994) Genetic associations with human longevity at the APOE and ACE loci. Nature Genet 6:29-32

Stadtman ER (1988) Protein modification in aging. J Gerontol 43:B112-120

Stephens JC, Reich DE, Goldstein DB, Shin HD, Smith MW, Carrington M, Winkler C, Huttley GA, Allikmets R, Schriml L, Gerrad B, Malasky M, Ramos MD, Morlot S, Tzetis M, Oddoux C, di Giovine FS, Nasioulas G, Chandler D, Aseev M, Hanson M, Kaladjieva L, Glavac D, Gasparini P, Kanavakis E, Claustres M, Kambouris M, Ostrer H, Duff G, Baranov V, Sibul H, Metspalu A, Goldman D, Martin N, Duffy D, Schmidtke J, Estivill X, O'Brien SJ, Dean M (1998) Dating the origin of the CCR5- $\triangle 32$ AIDS-resistance allele by the coalescence of haplotypes. Am J Hum Genet 62:1507-1515

Tsai W, Clarke S (1994) Amino acid polymorphisms of the human Lisoaspartyl/D-aspartyl methyltransferase involved in protein repair. Biochem Biophys Res Commun 203:491-497

van der Put NMJ, van den Heuvel LP, Steegers-Theunissen RPM, Trijbels FJM, Eskes TKAB, Mariman ECM, den Heyer M, Blom HJ (1996) Decreased methylene tetrahydrofolate reductase activity due to the $677 \mathrm{C} \rightarrow \mathrm{T}$ mutation in families with spina bifida offspring. J Mol Med 74:691-694

Vidgren J, Svensson LA, Liljas A (1994) Crystal structure of catechol O-methyltransferase. Nature 368:354-358

Weinshilboum RM (1992) Methylation pharmacogenetics: thiopurine methyltransferase as a model system. Xenobiotica 22:1055-1071 